UNIVERSITY OF COPENHAGEN

Dual Income Taxes

A Nordic Tax System

Sørensen, Peter Birch

Publication date:

2009

Document version

Publisher's PDF, also known as Version of record

Citation for published version (APA):

Sørensen, P. B. (2009). Dual Income Taxes: A Nordic Tax System. Economic Policy Research Unit. Department of Economics, University of Copenhagen. 
Economic Policy Research Unit

Department of Economics

University of Copenhagen

$\emptyset$ ster Farimagsgade 5, Building 26

DK-1353 Copenhagen $\mathrm{K}$

DENMARK

Tel: (+45) 35324411

Fax: (+45) 35324444

Web: http://www.econ.ku.dk/epru/

Dual Income Taxes: A Nordic Tax System

Peter Birch Sørensen 


\title{
DUAL INCOME TAXES: \\ A NORDIC TAX SYSTEM
}

\author{
by \\ Peter Birch Sørensen \\ Department of Economics \\ University of Copenhagen
}

Revised version of paper

originally presented at the conference on

New Zealand Tax Reform - Where to Next?

at the Victoria University of Wellington,

11-13 February, 2009

Address for correspondence:

Peter Birch Sørensen

Department of Economics, University of Copenhagen

Studiestraede 6, 1455 Copenhagen K, Denmark

E-mail:pbs@econ.ku.dk 


\section{DUAL INCOME TAXES: A NORDIC TAX SYSTEM}

by Peter Birch Sørensen ${ }^{1}$

During the early 1990s the Nordic countries undertook a series of sweeping tax reforms. These reforms combined ambitious base-broadening measures with the introduction of the so-called dual income tax which systematically separates the taxation of labour income from the taxation of capital income. In recent years elements of dual income taxation have been introduced in several OECD countries (see Eggert and Genser, 2005), and variants of the dual income tax have been proposed for countries like Germany (Spengel and Wiegard, 2004, Sinn, 2007), Switzerland (Keuschnigg and Dietz, 2007) and the United Kingdom (Griffith, Hines and Sørensen, 2008).

This paper discusses the principles and practices of dual income taxation in the Nordic countries. The first part of the paper explains the rationale and the historical background for the introduction of the dual income tax and describes the current Nordic tax practices. The second part of the paper focuses on the problems of taxing income from small businesses and the issue of corporate-personal tax integration under the dual income tax, considering alternative ways of dealing with these challenges. In the third and final part of the paper, I briefly discuss whether introducing a dual income tax could be relevant for New Zealand.

\section{PART 1. PRINCIPLES OF DUAL INCOME TAXATION}

\subsection{What is a dual income tax?}

The Nordic dual income tax (henceforth termed the DIT) is a particular form of schedular income tax which combines progressive taxation of labour and transfer income with a low flat tax on all capital income. In the pure version of the system the flat tax rate on capital income is aligned with the corporate income tax rate and with the marginal tax rate on labour income in the first bracket. In this case the DIT may be described as a system that combines a flat tax on total income with a progressive surtax on labour and transfer income.

An important part of the philosophy underlying the DIT is that the capital income tax base should be broad, to ensure the greatest possible degree of tax neutrality. Under a consistent DIT, the personal capital income tax base would thus include the following components:

\footnotetext{
${ }^{1}$ Professor of Economics, University of Copenhagen, and Head Chairman of the Danish Economic Councils.
} 
interest

- dividends

capital gains

rental income

royalties

imputed returns on owner-occupied housing

imputed returns on capital invested in non-corporate firms

In case the sum of these components is negative, the taxpayer is entitled to a tax credit equal to the capital income tax rate times the negative balance.

The quest for tax neutrality was well reflected in the Norwegian DIT introduced in 1992 which aimed to tax all capital income once but only once. Hence the Norwegian tax reform involved full alleviation of the double taxation of corporate income. For distributed corporate profits, this was achieved by aligning the corporate income tax rate with the personal capital income tax rate and by offering a full imputation credit for the underlying corporation tax against the personal capital income tax on dividends. For retained corporate profits, double taxation was avoided by allowing shareholders to add (their proportionate share of) the company's retained taxable profits to the basis of their shares when calculating the taxable capital gain on shares. Further, to achieve rough neutrality in the tax treatment of wage earners and entrepreneurs, the Norwegian DIT split the income from self-employment and from small companies into an imputed return to capital, taxable as capital income, and a residual income subject to labour income tax. Under the Norwegian DIT the capital income tax base also included an imputed return to owneroccupied housing, albeit based on assessed property values that were typically well below market values.

Before discussing the rationale for the dual tax system outlined above, it may be useful to consider how it relates to various other 'grand designs' for the personal tax system.

\subsection{The dual income tax versus other blueprints for the personal tax system}

Historically the personal tax systems of most OECD countries have been inspired by the philosophy of the progressive comprehensive income tax. Under this tax system the taxpayer's net incomes from all sources are added together, and this sum total is then subject to a progressive tax schedule with rising marginal tax rates. Ideally, comprehensive income in the sense of Schanz-Haig-Simons 
is defined as the increase in the taxpayer's purchasing power over the tax period. Hence income should be measured in real terms, with appropriate inflation adjustment of nominal returns to capital, and all accrued real capital gains (losses) should be taxed (deducted), whether they have been realized or not.

Apart from its consistency with a particular notion of equity in taxation - that all those with the same purchasing power, however they derive it, should pay the same amount of tax - the comprehensive income tax has the appeal of eliminating any incentive to artificially transform one kind of income into another, since the taxpayer faces the same marginal tax rate on all types of income. Yet, in practice governments have been reluctant to tax unrealized capital gains and other forms of accrued income such as returns to institutional saving, because such income may be hard to measure and/or because the taxpayer may lack the liquidity needed to pay tax on unrealized income. Hence, to the extent that capital gains are taxed at all, the tax is typically deferred until the time of realization, giving rise to the well-known lock-in effect and implying a tax preference for capital gains, due to the benefit from tax deferral. Moreover, in practice the returns to nominal assets are rarely subject to systematic adjustment for inflation before being subject to tax, so the effective tax rate on real income may deviate substantially from the statutory tax rate.

Because of these and other problems with (the practical implementation of) the comprehensive income tax, many academics have favoured the expenditure tax under which all savings would be deductible from the tax base whereas all dissavings would be added to the base so that tax would be levied on the taxpayer's consumption rather than on her income. A key feature of the expenditure tax is that the after-tax return to savings is the same as the before-tax return on the underlying asset, provided the marginal tax rate is constant over time. ${ }^{2}$ Thus the expenditure tax is broadly equivalent to a tax system that exempts the normal return to saving from tax. Because it taxes the taxpayer's observed net cash inflow rather than her accounting income, the expenditure tax tends to avoid the practical problems involved in implementing a comprehensive income tax on accrued capital income. However, while economic theory provides good reasons why capital income should not necessarily be taxed at the same rate as labour income, it also provides several

\footnotetext{
${ }^{2}$ To illustrate: suppose the taxpayer purchases an asset worth $\$ 100$ in year 1 and sells it in year 2 at a price of $\$ 110$, thus scoring a 10 percent rate of return before tax. In year 1 , the taxpayer may deduct the purchase price of $\$ 100$ from her tax base, so if the marginal tax rate is 50 percent, her net outlay will be $\$ 50$. In year 2 when the sales price of the asset is added to the tax base, her after-tax revenue from the asset sale will be $\$ 55$. Hence the taxpayer has earned an after-tax rate of return of (55-50)/50=10 percent, corresponding to the pre-tax rate of return. Note that since the government participates with an equal share in all investment outlays and proceeds, the expenditure tax does ensure that the government receives a share of the profit whenever the pre-tax return to an investment exceeds the rate of return on government bonds. In this sense the expenditure tax implies that 'above-normal' returns to savings are taxed.
} 
reasons why a positive tax rate on capital income should be part of an optimal tax system (see Sørensen, 2007b). Moreover, because of the perceived transition problems and international complications involved in the switch to an expenditure tax, no OECD government has yet implemented such a tax system.

Recent years have witnessed an increased interest in the so-called flat tax which imposes a constant marginal tax rate on income or consumption above the personal exemption level (see Keen et al., 2006). The flat tax advocated by Hall and Rabushka (1995) is essentially a linear consumption tax and hence equivalent to a linear expenditure tax, since the Hall-Rabuska tax exempts capital income and allows full expensing of all business investment. However, the flat taxes that have recently spread throughout Eastern Europe typically include some or all capital income in the tax base. In these cases the flat tax is just a linear variant of the comprehensive income tax.

The Nordic DIT combines a flat tax on capital income with a progressive labour income tax schedule where the marginal tax rate rises with the level of labour income. The DIT may be seen as a compromise between the comprehensive income tax and the expenditure tax. Whereas the expenditure tax completely exempts the normal return to capital from tax, the DIT imposes a positive tax on income from capital, but at a low flat rate below the top marginal tax rate on labour income.

Like the DIT, the so-called comprehensive business income tax (CBIT) once proposed by the U.S. Treasury (1992) also combines a flat tax on capital income with a progressive labour income tax. Under the CBIT, interest expenses would no longer be deductible from taxable profits, and business income would be subject to a flat (corporate) tax rate (roughly) equal to the top marginal personal income tax rate. In this way interest, dividends and capital gains would be taxed at source and would therefore be exempt at the individual investor level, since the business income tax would serve as a final withholding tax on capital income. Labour income would continue to be taxed according to a progressive tax schedule, so the marginal rates applying at low levels of income would fall below the business income tax rate. Being source-based, the CBIT would apply equally to foreign and domestic investors supplying capital to the domestic economy.

Thus, while the CBIT aligns the flat capital income tax rate with the top marginal personal tax rate, the pure version of the DIT aligns the capital income tax rate and the corporate income tax rate with the marginal personal tax rate in the first bracket. Moreover, although the DIT could be implemented as a pure source-based tax, as proposed by Cnossen (2000), the tax treaties 
signed by the Nordic countries typically imply that no withholding taxes are levied on interest and dividends paid out to non-resident investors, so in practice the DIT is a residence-based tax.

\subsection{The case for the dual income tax ${ }^{3}$}

Compared to a traditional income tax, the unconventional feature of the DIT is that it combines a flat tax on capital income with progressive taxation of labour income. At the theoretical level, it can be argued that such a system is desirable because it serves to equalize the tax treatment of nonhuman and human capital investment (see Nielsen and Sørensen, 1997). If the labour income tax were purely proportional, it would tend to exempt the return to human capital investment from tax. To illustrate, suppose a taxpayer with a potential income of $\$ 100,000$ in period 1 decides to enroll in an education program which raises his potential income in period 2 to $\$ 210,000$. By sacrificing an income of $\$ 100,000$ in the first period, he can thus raise his income in period 2 by $\$ 110,000$, implying a 10 percent pre-tax rate of return to his human capital investment. If labour income is taxed at a flat rate of 50 percent, the net income foregone in year 1 is $\$ 50,000$, while the increase in after-tax income obtainable in year 2 is $\$ 55,000(=0.5 \times 110,000)$, so measured in after-tax terms the return to human capital investment is still equal to the 10 percent pre-tax rate of return. By contrast, the income tax does reduce the net return obtainable on physical and financial investments. Thus a purely proportional income tax will tend to favour human over non-human capital investments. But if the labour income tax were progressive, with higher levels of income being subject to higher marginal tax rates, the returns to human capital investments would likewise be curbed by the tax system, thereby tending to eliminate the tax distortion in favour of such investments. ${ }^{4}$

However, while the above theoretical argument has played a certain role in academic discussions of the DIT, policy makers have been rather more persuaded by a number of practical and pragmatic considerations that speak in favour of setting a relatively low and flat tax rate on capital income. The case for a low marginal tax rate on income from capital rests on the following arguments:

\footnotetext{
${ }^{3}$ This section draws on Sørensen (1994) where the reader may find a more detailed account of the background for the introduction of the DIT in the Nordic countries.

${ }^{4}$ This argument by Nielsen and Sørensen (1997) assumes that policy makers have committed themselves to levying a positive tax on the returns to non-human capital, say, for distributional reasons. Jacobs and Bovenberg (2008) assume instead that policy makers have committed themselves to redistribute income through a progressive labour income tax which discourages human capital investment. They then show that it is optimal to supplement the progressive labour income tax with a positive flat tax rate on capital income to offset the tax disincentive to human capital formation. According to their model simulations, it will usually be optimal to keep the capital income tax rate below the top marginal labour income tax rate, as under the Nordic DIT.
} 
- Inflation: Income tax is typically levied on the full nominal return to capital, including the inflation premium that compensates for the erosion of the real value of nominal assets. Thus many forms of capital income are overtaxed if charged at the top marginal tax rate applying to labour income.

Capital mobility: As the international mobility of capital increases, there is a growing risk that a high domestic capital income tax rate will induce taxpayers to move their wealth abroad, particularly to foreign low-tax jurisdictions, making it very difficult to bring that income into the domestic tax net. Setting a low domestic capital income tax rate reduces the risk of capital flight.

- Tax neutrality: Capital income accrues in many forms, some of which are hard to tax (for practical or political reasons). Lowering the tax rate on those types of capital income that can be taxed reduces the distortions arising when certain types of capital income cannot be included in the tax base. A low tax rate also makes it easier to broaden the tax base, for instance by including capital gains without causing severe lock-in effects.

In addition, proponents of the DIT offer the following arguments in favour of a flat rather than a progressive tax on capital income:

Lock-in effects: Capital gains taxation based on the realization principle generates a lock-in effect which hampers the reallocation of capital towards more productive uses. Progressive taxation of realized gains exacerbates this lock-in effect because the taxpayer may be pushed into a higher tax bracket in the year of realization. A low flat tax on capital income avoids this additional distortion.

Tax arbitrage: Aligning the corporate with the personal tax rate on capital income, and equalizing marginal capital income tax rates across taxpayers, eliminates the scope for tax arbitrage activities that seek to exploit such differences in tax rates.

Clientele effects: Under a progressive capital income tax investors in high-income brackets may choose to specialize in holding assets whose returns accrue in tax-favoured form (e.g. in the form of capital gains benefiting from tax deferral). Since the productivity of assets may depend on who 
owns them, such tax distortions to ownership patterns may be undesirable. A switch to proportional capital income taxation will reduce such distortions.

- Tax administration: A flat tax rate on capital income simplifies tax administration by allowing the tax on interest and dividends to be collected as a final withholding tax.

The argument that the lack of inflation adjustment under a conventional income tax implies overtaxation of nominal capital income played an important role in persuading Nordic policy makers (including left-leaning Social Democrats) of the fairness of the DIT. Even at low rates of inflation this argument still has considerable force, since a low inflation rate tends to go hand in hand with low nominal interest rates. For example, suppose the rate of inflation is 2 percent, while the nominal interest rate is 4 percent, implying a 2 percent real interest rate. If the tax rate levied on nominal interest income is 50 percent, the capital income tax would then confiscate all of the 2 percent real rate of return, that is, the effective tax rate on the real interest income would be a punitive 100 percent!

Nordic policy makers also recognized that, in an economy where a large proportion of private savings is channelled into tax-favoured assets like owner-occupied housing and retirement savings accounts or assets yielding low-taxed or tax-exempt capital gains, a high marginal tax rate on other forms of capital income is not a very effective means of redistributing income from the rich to the poor. In such an environment, even high marginal tax rates on the returns to the nonfavoured assets are likely to generate little revenue while causing large distortions to the pattern of saving and investment. Indeed, in countries like Norway and Sweden with liberal rules for the deductibility of interest expenses, the personal capital income tax actually caused a huge revenue loss in the late 1980s because of extensive debt-financed household investments in tax-favoured assets. In particular, many taxpayers in high-income brackets took advantage of tax asymmetries to reduce their tax liability. When the marginal tax rate on capital income was lowered through the transition to the DIT, the revenue loss from interest deductibility and the scope for tax arbitrage was reduced considerably. Paradoxically, the sharp reduction of capital income tax rates thus generated a significant revenue gain which enabled the Nordic governments to lower the tax burden on labour income.

The Nordic experience also suggests that, by lowering the capital income tax rate through the transition to a DIT, it becomes easier (economically and politically) to reduce tax non- 
neutralities through a broadening of the capital income tax base. In particular, a low flat tax capital income tax rate facilitates the taxation of realized capital gains by reducing the familiar lock-in effects. When switching to the DIT, Norway and Sweden did in fact tighten their capital gains tax rules quite considerably.

In summary, the Nordic governments abandoned high progressive taxes on capital income, not because they gave up their traditional distributional policy goals, but because they realized that a high progressive tax on (some forms of) capital income is an inefficient means of redistributing income compared to a progressive labour income tax. After all, much capital income derives from savings out of labour income, and inequalities stemming from large inherited stocks of wealth may be better addressed through instruments such as an inheritance tax. Moreover, when the capital income tax rate is not too high, it becomes easier to move towards a comprehensive capital income tax base which in turn tends to improve horizontal as well as vertical equity among taxpayers.

\subsection{The critique of the dual income tax}

A balanced assessment of the DIT must of course acknowledge the weaknesses as well as the strengths of the system. In particular, while the switch to a low uniform tax on all capital income reduces the scope for many tax arbitrage activities, it also opens up new possibilities for income shifting by taxpayers who are able to transform high-taxed labour income into low-taxed capital income. The special provisions needed to contain such income shifting may be seen as the Achilles heel of the DIT; they are the subject of Part 2 of this paper.

In the eyes of many observers, the growing international mobility of capital has tended to strengthen the case for the DIT, since a low capital income tax rate reduces the risk of capital flight. However, some participants in the Nordic tax policy debate have challenged this viewpoint, arguing that the capital flight problem mainly relates to a source-based capital income tax like the corporation tax, whereas the problem is much smaller under a residence-based tax like the personal income tax, since individuals are much less mobile than capital. According to this view, the marginal personal tax rate on capital income should be kept in line with the marginal personal tax rate on labour income to preserve horizontal equity and eliminate possibilities for income shifting, while the capital flight problem should be addressed by setting the corporate income tax rate well below the top marginal personal tax rate. 
While influential among Nordic tax lawyers, this view has met with opposition from tax economists who point out that as long as capital gains on shares cannot be taxed at the time of accrual, a corporate tax rate well below the personal capital income tax rate would generate a strong incentive to accumulate income within existing corporations even if the capital could be invested more productively elsewhere. Indeed, the evidence from OECD countries suggests that, on average, a one percentage point cut in the corporate tax rate (keeping the personal tax rate on interest income constant) generates a 2.6 percentage point increase in the fraction of private savings channelled through the corporate sector (see Fuest and Weichenrieder, 2002). A large positive gap between the marginal personal capital income tax rate and the corporate tax rate is thus likely to have a strong distortionary lock-in effect on capital invested in existing corporations. Even though the capital flight argument may seem most relevant in the context of corporate income taxation, it is therefore desirable to keep the personal capital income tax rate roughly in line with the corporate tax rate to avoid lock-in effects hampering the free flow of capital towards its most productive uses. ${ }^{5}$ Moreover, because of the well-known practical difficulties of monitoring foreign source capital income, a high personal capital income tax rate may in fact induce some capital flight even if the investor maintains his domestic residence.

\subsection{Alternative visions for the dual income tax and current Nordic practices}

An important policy choice in the design of a DIT is whether the low flat tax rate on capital income should apply to the full return to capital or only to a 'normal' rate of return. When the DIT was first introduced in the Nordic countries, the flat capital income tax was intended to fall on the full return to capital. In particular, the imputed returns to capital invested in small businesses included a generous risk premium, and the flat tax rate on corporate source income was levied on the 'equity premium' as well as on the normal risk-free return.

However, from 2006 Norway switched to an alternative version of the DIT in which the flat capital income tax rate applies only to the 'normal' rate of return on shares. Under the new Norwegian tax system shareholder income (dvidends plus capital gains on shares) exceeding an imputed normal return carries a combined corporate and personal tax burden very close to the top marginal tax rate on labour income. As section 2.2.2 will explain, the attraction of imposing an additional layer of tax on above-normal returns is that this will eliminate the incentive for income shifting under the DIT in a manner that does not distort investment incentives.

\footnotetext{
${ }^{5}$ In subsection 2.2.4 and in Part 3 I shall return to the issue whether a serious lock-in effect can in fact be avoided in cases where the corporate tax rate is significantly lower than the personal capital income tax rate.
} 
Table 1. Dual income taxation in the Nordic countries (2008, tax rates in percent)

\begin{tabular}{|c|c|c|c|}
\hline & Finland & Norway & Sweden \\
\hline $\begin{array}{l}\text { Personal tax rate on } \\
\text { - capital income } \\
\text { - labour income }\end{array}$ & $\begin{array}{c}28 \\
27-50\end{array}$ & $\begin{array}{c}28 \\
28-48\end{array}$ & $\begin{array}{c}30 \\
31.5-56.5\end{array}$ \\
\hline $\begin{array}{l}\text { Offset of negative capital } \\
\text { income }\end{array}$ & $\begin{array}{c}\text { Deductible against } \\
\text { positive capital income }\end{array}$ & $\begin{array}{l}\text { Deductible against other } \\
\text { income in the first tax bracket }\end{array}$ & Tax credit \\
\hline Corporate income tax rate & 26 & 28 & 28 \\
\hline $\begin{array}{l}\text { Integration of corporate and } \\
\text { personal income tax }\end{array}$ & $\begin{array}{l}\text { Quoted companies: } \\
\text { Only } 70 \text { percent of } \\
\text { dividends are taxed } \\
\text { (as capital income) } \\
\text { Unquoted companies: } \\
\text { Dividends below an } \\
\text { imputed return on shares } \\
\text { are exempt from personal } \\
\text { tax; and only } 70 \text { percent } \\
\text { of dividends above that } \\
\text { limit are taxed (as labour } \\
\text { income) }\end{array}$ & $\begin{array}{l}\text { Only dividends and capital } \\
\text { gains in excess of an imputed } \\
\text { rate of return on shares are } \\
\text { taxed (as capital income) }\end{array}$ & $\begin{array}{l}\text { Quoted companies: } \\
\text { No integration } \\
\text { Unquoted companies: } \\
\text { Dividends and capital } \\
\text { gains on unquoted } \\
\text { shares are taxed at } \\
\text { reduced rates (see notes } \\
3 \text { and 5) }\end{array}$ \\
\hline $\begin{array}{l}\text { Personal tax rate on } \\
\text { - dividends } \\
\text { - capital gains on shares } \\
\text { Withholding tax rate }^{6} \text { on }\end{array}$ & $\begin{array}{ll}19.6 & (=0.7 \times 28) \\
& 28\end{array}$ & $\begin{array}{l}28^{2} \\
28^{4}\end{array}$ & $\begin{array}{l}30^{3} \\
30^{5}\end{array}$ \\
\hline $\begin{array}{l}\text { - interest } \\
\text { - dividends }\end{array}$ & $\begin{array}{l}28 \\
19\end{array}$ & $\begin{array}{c}28 \\
0\end{array}$ & $\begin{array}{l}30 \\
30\end{array}$ \\
\hline
\end{tabular}

Source: Author's compilation of information from the International Bureau of Fiscal Documentation.

1. 70 percent of dividends exceeding 90,000 euros but falling below the imputed return are taxed as capital income.

2. Applies only to dividends in excess of an imputed rate of return on the shares.

3. For active owners of closely held companies, dividends below an imputed return are taxed at a reduced rate of $20 \%$ while dividends above the imputed return are taxed as labour income. Dividends received by 'passive' owners of unquoted companies are taxed at a reduced rate of $25 \%$.

4. Applies only to capital gains in excess of an imputed rate of return on the shares.

5. For active owners of closely held companies, capital gains below an imputed return are taxed at a reduced rate of $20 \%$ while gains above the imputed return are taxed as labour income. Gains realized by 'passive' owners of unquoted companies are taxed at a reduced rate of $25 \%$.

6 . For domestic residents.

\section{Table 1 provides an overview of current tax practices in Finland, Norway and} Sweden. ${ }^{6}$ In these countries, the flat capital income tax rate ranges between 28 and 30 percent. This is roughly in line with both the corporate tax rate and the lowest marginal rate in the labour income tax schedule, but far below the top marginal tax rate on labour income. Because of the 'flatness' of

\footnotetext{
${ }^{6}$ Denmark was the first country to introduce the DIT, in 1987, but has subsequently moved to a hybrid between the comprehensive income tax and DIT. It is therefore not included in Table 1.
} 
the capital income tax, it can in many cases conveniently be collected by final withholding. However, for symmetry and neutrality, the Nordic countries offer a tax credit for negative net capital income, or allow it to be offset against positive income in the first tax bracket. Though it was originally part of the DIT philosophy to avoid double taxation of corporate source income, the Nordic countries have not fully done so, although Norway comes close by exempting an imputed normal return to all shares from taxes on dividends and capital gains. The next part of the paper will include a discussion of corporate-personal tax integration under the DIT.

\section{PART 2. TAXING BUSINESS INCOME UNDER THE DUAL INCOME TAX ${ }^{7}$}

The key distinction under the DIT is that between capital income and other income. Implementing this distinction is mainly a challenge in the area of business income taxation. This part of the paper considers alternative options for the taxation of business income under the DIT and describes the Nordic practices in this area.

\subsection{Taxing income from self-employment under the dual income tax}

\subsubsection{Design issues}

The self-employed work in their own business, so part of their business income must be seen as labour income. At the same time, the self-employed have also invested (part of) their wealth in their business, so another part of their income is a return to their business assets which is clearly a form of income from capital. If all of the business income of the self-employed were taxed as labour income at progressive rates, their capital income would be overtaxed relative to other types of capital income under a DIT. On the other hand, if all income from self-employment were taxed at the low flat rate applying to capital and corporate income, the self-employed would escape tax progressivity altogether, even though part of their income stems from their work effort.

To avoid such unequal tax treatment, it is necessary to split the income of the selfemployed into a labour income component and a capital income component. Since the working hours and effort of the self-employed cannot be observed by the tax authorities, whereas the stock of business assets can in principle be observed, it is natural to split the income of the self-employed

\footnotetext{
${ }^{7}$ This part of the paper draws on Hagen and Sørensen (1998) and particularly on Sørensen (2007a). These articles provide further details on the design of business income taxation under a DIT.
} 
by first imputing a rate of return to their business assets, which is categorized as capital income, and then treat the residual business profit as labour income.

The imputed rate of return to business assets may be computed on a 'gross assets' or on a 'net assets' basis. Under the 'gross assets' method, the net financial liabilities of the firm are not deducted from the asset base. The labour income of the entrepreneur is thus calculated by deducting an imputed return to 'gross' business assets (the assets recorded in the firm's balance sheet) from the 'gross' profits of the firm (defined as profits before interest), and taxable net capital income is calculated by deducting interest expenses from the imputed return to the gross assets. To illustrate, let $Y$ denote business income before deduction for interest, let $A$ indicate the stock of business assets recorded in the firm's balance sheet, and let $D$ denote the stock of business debt. If $r$ is the rate of return imputed to business assets, and $i$ is the actual interest rate paid on business debt, the imputed capital income $\left(C_{G}\right)$ and the imputed labour income $\left(W_{G}\right)$ under the gross assets method is calculated as follows:

Income splitting under the gross assets method

$$
\begin{aligned}
& C_{G}=r A-i D \\
& W_{G}=Y-r A
\end{aligned}
$$

By contrast, under the 'net assets' method capital income is determined by imputing a return to the net assets of the firm (business assets minus business debt), and labour income is found by deducting this imputed return from net profits (profits after deduction for interest). If $C_{N}$ and $W_{N}$ denote the imputed capital income and labour income under the net assets method, we thus have:

Income splitting under the net assets method

$$
\begin{gathered}
C_{N}=r(A-D) \\
W_{N}=Y-i D-C_{N}=Y-i D-r(A-D)
\end{gathered}
$$

From these equations it follows that

$$
\begin{aligned}
& C_{G}-C_{N}=(r-i) D \\
& W_{G}-W_{N}=(i-r) D
\end{aligned}
$$


If the imputed rate of return equals the rate of interest paid on business debt $(r=i)$, the two methods will thus be equivalent, generating exactly the same split of total business income into capital income and labour income. But if the imputed return exceeds the interest rate, a larger fraction of business income will be categorized as capital income (and a correspondingly lower fraction will be taxed as labour income) under the gross assets method than under the net assets method. The opposite will hold if the imputed return is lower than the interest rate.

Moreover, deviations between the imputed return and the interest rate on debt will tend to distort business investment under the gross assets method. To see this, let $t$ denote the flat capital income tax rate, and let the function $T(W)$ indicate the progressive tax schedule for labour income. From (1) and (2), we then find that the entrepreneur's total tax bill under the gross assets method $\left(T_{G}\right)$ will be

$$
T_{G}=t C_{G}+T\left(W_{G}\right)=t(r A-i D)+T(Y-r A)
$$

Now suppose the entrepreneur undertakes an additional debt-financed investment of \$1. Suppose further that this additional investment raises business income by the amount $\Delta Y=i$. In the absence of tax, the investment would thus barely be worth undertaking since it generates a pre-tax return which is just sufficient to cover the interest on the additional debt. With $m \equiv T^{\prime}(W)$ denoting the marginal tax rate on labour income, and with $A$ and $D$ both increasing by one unit, we see from (7) that the change in the entrepreneur's total tax bill $\left(\Delta T_{G}\right)$ will be equal to

$$
\Delta T_{G}=t(r-i)+m(i-r)=(t-m)(r-i)
$$

If the imputed rate of return exceeds the rate of interest $(r>i)$ and if the marginal labour income tax rate exceeds the capital income tax rate $(m>t)$, we see from $(8)$ that the extra investment reduces the entrepreneur's tax bill. The reason is that a larger share of total profit gets taxed at the low capital income tax rate rather than at the high marginal labour income tax rate. Hence an investment that would not yield any net profit in the absence of tax actually becomes profitable in the presence of tax. Thus taxation under the gross assets method artificially stimulates investment when the imputed return exceeds the interest rate. On the other hand, if the imputed return falls 
short of the interest rate at which the entrepreneur can borrow, the gross assets method of taxation artificially discourages investment.

By contrast, under the net assets method of income splitting, the entrepreneur's total tax bill $\left(T_{N}\right)$ is given as

$$
T_{N}=t C_{N}+T\left(W_{N}\right)=\operatorname{tr}(A-D)+T(Y-i D-r(A-D))
$$

Since the recorded net assets of the firm $(A-D)$ are unaffected by an additional unit of debtfinanced investment, and since profits net of interest are likewise unaffected in our example where $\Delta Y=i$, we see from (9) that the entrepreneur's total tax bill is unchanged, since neither the imputed capital income nor the imputed labour income will change. Hence the net assets method of incomesplitting ensures that the DIT remains neutral towards marginal investment decisions.

This analysis would seem to imply a preference for the net assets method on tax neutrality grounds, but unfortunately this method also allows greater scope for tax arbitrage. To see how, note from (9) that under the net assets method interest expenses become deductible against the high marginal tax rate on labour income, because they reduce the residual net profit which is taxed as labour income. This provides an incentive for entrepreneurs with high earnings to record private debt (debt incurred for non-business purposes, say, to finance the purchase of a consumer durable or a piece of real estate) as business debt in order to benefit from interest deductibility.

To limit the scope for such transactions, the self-declared business income should be adjusted in cases where the declared net assets of the firm become negative, since negative net business assets indicate that private debt has been transferred to the business sphere. Specifically, taxable business income should be raised by the imputed return times the recorded negative net worth of the firm to (roughly) offset the fact that reported business income has been artificially lowered by allocating non-business interest expenses to the firm. To the extent that the tax law allows deduction for non-business interest expenses, the upward adjustment of taxable business income should of course be accompanied by a corresponding downward adjustment of the entrepreneur's non-business capital income (which might well be negative, in which case the entrepreneur would receive a tax credit equal to the capital income tax rate times the negative capital income).

The net assets method may also require a similar adjustment of taxable business income in certain other cases in order to prevent tax arbitrage, as explained in Sørensen (2007a, pp. 
570-571). Thus the choice between the gross and the net assets method involves a trade-off between the superior neutrality properties of the net assets method and the greater simplicity and lower vulnerability to tax arbitrage offered by the gross assets method.

Another avoidance problem arising under both methods of income-splitting is that entrepreneurs may gain by transferring low-yielding non-business assets (e.g., a piece of real estate or a motor vehicle used for private consumption) from the private sphere to the business sphere. By adding to the recorded stock of business assets an asset with little or zero (taxable) yield, the entrepreneur will have a higher proportion of his business income taxed as capital income, since the base for calculating the imputed return goes up, while total business income stays (almost) unchanged. To prevent such transformation of labour income into capital income, the tax law must include clauses limiting the scope for transferring non-business assets to the business sphere.

When determining the rate of return imputed to business assets, policy makers must decide whether to include a risk premium in the imputed return. The case for doing so depends critically on the tax treatment of losses. If the tax code allows full loss offsets ${ }^{8}$ and the marginal tax rate on business income is constant over time, it is not necessary to include a risk premium in the imputed return to avoid discouraging investment and risk-taking, as shown by Sørensen (2007a, pp. 572-573). Indeed, in this case the DIT will actually stimulate risk-taking even when the imputed return contains no risk premium. The reason is that, with full loss offsets, the high labour income tax rate imposed on residual business income works as an insurance device which reduces the variability (and hence the riskiness) of after-tax business income.

However, because of the risk of abuse, the tax code rarely allows full loss offset. Moreover, if marginal business income is taxed progressively as labour income, losses incurred in bad years will often be deducted against a lower tax rate than the marginal tax imposed on profits accruing in good years. If these tax asymmetries are strong, the tax system will tend to discourage risk-taking. In that situation there is a case for including a risk-premium in the imputed return on business assets which is taxed as capital income. Ideally, the imputed risk premium should vary with the risk characteristics of each individual investment project, but since tax authorities lack the information and the administrative capacity to undertake a detailed differentiation of risk premia, they may choose to apply the same risk premium across the board. Inevitably, this premium will be too high for some investment projects and too low for others, implying some distortion to the pattern of risk-taking.

\footnotetext{
${ }^{8}$ This would involve unlimited carry-forward of losses with interest to preserve the present value of the deduction.
} 


\subsubsection{Nordic practices}

The Nordic DIT countries all provide an option for the self-employed to have their income split into a capital income component and a labour income component. Norway uses a variant of the gross assets method, while Finland and Sweden practice variants of the net assets method. Apart from distinguishing between labour and capital income, the Swedish scheme also allows imputed labour income retained in the firm to be taxed at the low corporate income tax rate, postponing imposition of the progressive labour income tax until the time when profits are distributed.

Although Denmark does not apply a pure DIT, having maintained some amount of progressivity in the taxation of capital income, the country does tax labour income more heavily at the margin. Denmark therefore allows the self-employed to opt for a splitting of their business income into capital income and labour income. Entrepreneurs opting for income splitting may choose between the simpler gross assets method and a more complicated net assets method similar to the Swedish scheme.

\subsubsection{Final observations on income tax design for the self-employed}

In designing tax rules for the self-employed under the DIT, the following considerations should be kept in mind:

1) If the tax rate in the lowest bracket of the labour income tax schedule is aligned with the tax rate on capital income, entrepreneurs whose business income falls within the lowest tax bracket will have no need for income splitting, since they face the same marginal tax rate on capital income and labour income. If the upper threshold for the lowest tax bracket is set at a fairly high income level, many proprietors would never need to have their income split, allowing a considerable administrative simplification.

2) Income-splitting should be an option but not a requirement for the taxpayer, since it offers an opportunity for entrepreneurs to avoid over-taxation of the capital income component of their business income. If an entrepreneur does not opt for income-splitting, his business income will automatically be taxed as labour income. Income-splitting requires that taxpayers keep proper accounts of their assets and liabilities, so taxpayers wishing to benefit from the low tax rate on capital income will have an incentive to keep proper books rather than relying on simplified accounting. Switching to a dual income tax may therefore help to promote modern business recordkeeping in small enterprises, which may be desirable in itself. 
3) In part because it requires fewer anti-avoidance measures, the gross assets method is administratively simpler than the net assets method, for the revenue authorities as well as for taxpayers. If priority is given to simplicity and low compliance costs, there is a case for choosing the gross assets method of income-splitting.

\subsection{Taxation of closely held corporations under the dual income tax}

\subsubsection{The income shifting problem}

The taxation of small corporations with active owners working in their own business raises a similar issue as the taxation of the self-employed: part of the income from the company must be seen as a return to the capital invested in the firm, whereas another part is the reward for the work effort and skills of the owner(s). In the absence of special rules for these companies, the dividends and capital gains on shares realized by the owner would be treated as capital income under the DIT (perhaps with some form of relief for the underlying corporation tax), while the management salaries paid to the owner(s) would be treated as labour income. If the sum of the corporation tax and the personal tax on dividends and/or capital gains is less than the marginal tax rate on labour income, the owner has an obvious incentive to pay himself dividends or to realize a capital gain on (part of) his shares rather than paying himself a realistic salary.

\subsubsection{Taxing active shareholders like proprietors}

A possible solution to this problem would be to tax the income from small companies accruing to active, controlling shareholders in the same way as income from self-employment. This would imply that a fraction of corporate profits equal to the fraction of shares owned by 'active' shareholders working in their own company would be split into an imputed return on corporate assets, which would be taxed as capital income, and a residual profit that would be taxed as labour income. This income splitting would apply regardless of the actual amount of dividends or capital gains realized by the owners, so the owners would be unable to transform labour income into capital income by paying themselves lower salaries and instead taking out higher dividends or capital gains. The corporation tax would serve as a withholding tax on corporate profits, but it would be credited against the shareholder's personal tax bill to prevent double taxation of corporate equity income.

The main problem with this scheme is the difficulty of identifying the 'active' controlling shareholders who should be subject to mandatory income-splitting. It would seem 
natural to require mandatory income-splitting only in cases where the shareholder carries out a certain minimum amount of work in his company and where, in addition, he has a certain minimum (controlling) ownership share in the firm, possibly in conjunction with his closest relatives. If both these conditions are met, the shareholder will most likely be able to transform management salary or other labour income from the firm into dividends or capital gains to reduce his tax bill.

However, one can easily imagine several ways in which such rules could be circumvented. For example, a controlling shareholder might invite relatives or friends to step in as minority shareholders so that he is no longer subject to the income-splitting rules even if he maintains effective control over the firm's dividend policy. One can also imagine that dominant shareholders might exchange shares in each other's companies to avoid mandatory income-splitting without giving up control of their respective companies.

The Norwegian experience suggests that such tax avoidance is not just a theoretical possibility. As part of the transition to the DIT in 1992, Norway introduced mandatory incomesplitting rules for 'active' shareholders along the lines described above. Yet, between 1992 and 2000 the proportion of corporations subject to income splitting fell from 55 percent to 32 percent, indicating that a growing number of taxpayers were able to change status from 'active' to 'passive' shareholders.

More fundamentally, the dividing line between 'active' and 'passive' shareholders is essentially arbitrary and may lead to unequal tax treatment of shareholders who are for practical purposes in equal positions.

\subsubsection{An alternative solution: a shareholder income tax with a rate-of-return allowance}

Because of these difficulties, it seems desirable to avoid having to distinguish between active and passive shareholders. This section describes an alternative scheme which does not require this distinction. A version of this scheme has been implemented in Norway from the start of 2006, following recommendations from an expert committee. ${ }^{9}$

The basic principle of the scheme is simple: shareholder income below an imputed 'normal' return is tax exempt at the shareholder level, since such income has already been subject to corporation tax at a rate corresponding to the capital income tax rate, but dividends and capital gains in excess of the imputed normal return is subject to a personal shareholder income tax. By an appropriate choice of tax rates, the sum of the corporation tax and the personal shareholder income

\footnotetext{
${ }^{9}$ The present author was a member of that committee. The scheme described below is analysed more formally in Sørensen (2005).
} 
tax corresponds to the top marginal tax rate on labour income. Hence controlling shareholders can gain nothing by transforming labour income into shareholder income, thus obviating the need to split the income of 'active' shareholders.

The shareholder income tax is imposed only when income from the firm is distributed as a dividend or is realized as a capital gain on shares. In other words, the tax base is the realized income from the shares minus a Rate-of-Return-Allowance (RRA). The realized income is the sum of dividends and any realized net capital gain on the shares in the company. Dividends and capital gains are thus treated symmetrically. If the realized income falls short of the RRA, the unutilized RRA may be carried forward and deducted in a later year.

The RRA is calculated as an imputed rate of return times the basis of the share. The basis for the current year is the sum of the original basis and all unutilized RRAs from previous years, i.e, the original basis is stepped up year by year by any unutilized RRAs. This step-up is necessary to ensure that only capital gains in excess of the normal return are subject to shareholder income tax.

The imputed rate of return should correspond to a normal after-tax rate of return from investment in the capital market, since this is the taxpayer's opportunity cost of investing in shares rather than, say, bonds. At the same time, since the corporate tax rate corresponds to the capital income tax rate under a pure dual income tax, shareholder income not exceeding the imputed return should be left free of personal income tax to avoid double taxation of the normal return to investment. $^{10}$

The simple numerical example on the following page illustrates how the base for the shareholder income tax is calculated. We consider a shareholder who injects equity into a company at the start of year 1, receives a dividend at the end of year 1, and a dividend or a capital gain on the share at the end of year 2 . The imputed return on shares, the after-tax interest rate, and the return to the company's investment after corporation tax are all assumed to be 5 percent. Plausibly, we also assume that one dollar of retained profit will generate a one dollar increase in the market value of shares in the company, as long as the retained profit does not exceed the shareholder's tax-free imputed return.

\footnotetext{
${ }^{10}$ Companies could be required to keep a taxed profits account to ensure that only 'normal' dividends paid out of taxed profits are exempt from personal tax.
} 


\section{Year 1}

1. Injection of equity at the start of the year 1000

2. Profit after corporation tax (5\% of 1.) 50

3. Dividend 30

4. Retained profit (2.-3.) 20

5. RRA (5\% of 1.) 50

6. Unutilized RRA (5.-3.) 20

Year 2

7. Stepped-up basis of share (1.+6.) 1020

8. Profit after corporation tax $(5 \%$ of $(1 .+4)$.

9. RRA ( $5 \%$ of 7.$)$

Scenario 1: Shares are realized at the end of year 2

10. Revenue from sale of shares at the end of year $2(1 .+4 .+8$. $) \quad 1071$

11. Stepped-up basis of share at the start of year $2(=7) \quad$.

12. RRA for year $2(=9$.) 51

13. Taxable capital gain (10.-11.-12.) 0

\section{Scenario 2: All profits are distributed at the end of year 2}

17. Dividend at the end of year $2(4 .+8$.) 71

18. Total RRA (6.+9.) 71

19. Taxable dividend (17.-18.) 0

On these assumptions we see that whether the shareholder's return takes the form of dividends or capital gains, she will end up with zero taxable income in both scenarios. This illustrates the important point that the shareholder income tax is neutral with respect to investment and financing decisions. In the absence of the shareholder income tax, the investment considered in our example is just barely worth undertaking for the company since it yields a return that only just matches the market interest rate. The example shows that the shareholder income tax will not affect the profitability of such a 'marginal' investment, regardless of whether profits are distributed or retained in the company.

The neutrality of the shareholder income tax reflects its equivalence to a cash flow tax which is known to be neutral. This equivalence result (which assumes full loss offsets) is demonstrated formally in Sørensen (2005), and it may be explained intuitively as follows. A cash flow tax is neutral because it effectively makes the government a silent partner in all investment projects, sharing symmetrically in all gains and losses. Thus a cash flow tax allows full expensing 
of investment, generating an immediate tax reduction equal to the tax rate $t$ times the investment outlay K. Alternatively one might allow investors to deduct in all future periods a rate of return $R R A$ on the initial investment outlay, as the shareholder income tax actually does. When the future tax savings from the rate-of-return allowance are discounted at the market interest rate $i$, their net present value will be $N P V=t \cdot R R A \cdot K / i$. If we set $R R A=i$, as in our numerical example, we get $N P V=t \cdot K$, indicating that a shareholder income tax with a rate-of-return allowance equal to the market interest rate will ensure equivalence with the neutral cash flow tax, generating exactly the same tax liability in present value terms.

One attractive aspect of the neutrality of the shareholder income tax is that it does not induce shareholders to postpone realization of their shares in order to defer capital gains tax, even though the tax is levied only upon realization (see Sørensen, 2005, pp. 786-787). ${ }^{11}$ The intuition for this result is that if an investor realizes an accrued capital gain in order to reinvest his after-tax gain, he will not be taxed on the normal return to the reinvested gain under the shareholder income tax. By contrast, a conventional income tax discourages the realization of gains because it taxes the normal return to reinvested gains.

In a setting with uncertainty and risk, the neutrality of the shareholder income tax relies on the symmetry of the tax: whenever the realized rate of return $r$ falls short of the rate-ofreturn allowance $R R A$, the shareholder should ideally be granted a tax reduction equal to $t^{\bullet}(R R A-r)$ in present value terms, where $t$ is the (marginal) shareholder income tax rate. This may be achieved by allowing the taxpayer to offset any realized loss on a share against any taxable income from other shares during the same year, and by allowing any remaining loss to be carried forward indefinitely with interest to be offset against future shareholder income. As long as the taxpayer earns sufficient taxable shareholder income in the future, such a carry-forward rule will ensure full loss offset in present value terms. In cases where the taxpayer does not receive (sufficient) future income from shares, full neutrality would require that he be granted a tax credit equal to the shareholder income tax rate times his remaining loss, to be offset against his tax liability on other income. Note that to preserve symmetry and neutrality, the 'loss' on a share must be defined as $R R A-r$, that is, it must include the rate-of-return allowance. In other words, for tax purposes the taxpayer is deemed to incur a loss whenever his realized capital gain falls short of his RRA for the current year plus any unutilized RRAs carried over from previous years.

\footnotetext{
${ }^{11}$ The shareholder income tax is in fact a special case of the generalized cash flow tax described in Auerbach and Bradford (2004). The Auerbach-Bradford scheme ensures holding-period neutrality even though tax is due only when assets are realized.
} 
With such fully symmetric tax rules, one can show that the imputed rate-of-return allowance does not have to include a risk premium to ensure neutrality of the shareholder income tax (see Sørensen, 2005a). To understand this, note that if the future tax reductions due to the $R R A$ accrue with certainty, as will in principle be the case with full loss offsets, the future tax breaks should be discounted at the risk-free (after-tax) interest rate $i$, even if the other cash flows associated with the stock investment are uncertain. Hence the present value of the tax savings from an extra dollar of stock investment will be $N P V=t \cdot R R A / i$ (recall that $t$ is the shareholder income tax rate). If the $R R A$ is set equal to the risk-free interest rate $i$, we therefore get $N P V=t$, showing that the government effectively finances a fraction of the investment outlay corresponding to the fraction of the cash receipts from the investment that must be paid in tax. Essentially the government just participates in the investment as a silent partner, and adding another partner sharing symmetrically in gains and losses cannot be distortionary.

Note that when the rate-of-return allowance does not include a risk premium, the shareholder income tax becomes a tax on the equity premium, i.e., a tax on the difference between the return on shares and the risk-free interest rate. Since the equity premium is on average positive and quite substantial, this means that the shareholder income tax will on average collect a nonnegligible amount of revenue even with full loss offsets. ${ }^{12}$

In Norway where a version of the shareholder income tax was introduced from the $1^{\text {st }}$ of January 2006, the imputed rate of return is in fact set equal to the (after-tax) interest rate on 3month government bonds. These are practically risk free, but despite the fact that the RRA does not include a risk premium, Norwegian policy makers decided to impose certain limitations on loss offsets in order to prevent abuse. Specifically, an unutilized $R R A$ for one share cannot be used to reduce taxable capital gains on other shares or to reduce other taxable income. The concern was that unless such a limitation was introduced, taxpayers would engage in so-called year-end transactions simply with the purpose of reducing tax liability.

In the Norwegian context this potential tax avoidance problem arises because the RRA on a share is assigned to the taxpayer who owns the share at the end of the year. If an unutilized $R R A$ from a share were fully deductible against other income, a Norwegian personal taxpayer could purchase a share from a tax exempt corporate or institutional investor or from a foreign investor (for whom the RRA has no value) right before New Year and sell it again right after New Year. This would leave the taxpayer with an unutilized $R R A$ that could be used to shield other taxable income.

\footnotetext{
${ }^{12}$ Of course, the fact that the shareholder income tax only exempts the risk-free after-tax return also adds to its revenueraising capacity.
} 
The problem with year-end trades could be avoided if the $R R A$ for any given year only corresponds to the fraction of the year in which the taxpayer has owned the share. Indeed, this would seem the most accurate and consistent way of calculating the $R R A$, but it would also increase the burden of administering the shareholder income tax, by requiring the authorities to keep track of trades in shares occurring during the fiscal year. ${ }^{13}$ For administrative reasons, the Norwegian authorities therefore decided to assign the RRAs to the taxpayers owning the shares at the end of the year, relying instead on limitations on loss offsets to deal with the problem of tax-motivated yearend transactions.

As indicated by these observations, the rules for loss offsets and for the assignment of $R R A$ s under a shareholder income tax require careful consideration and may involve difficult tradeoffs between the goals of tax neutrality and administrative simplicity.

The tax treatment of dividends and capital gains exceeding the $R R A$ also requires some consideration. To ensure that 'active' shareholders cannot transform labour income into lightly taxed capital income, tax rates must be chosen such that

$$
(1-\tau)\left(1-t^{s}\right)=1-m \quad \Rightarrow \quad \tau+t^{s}(1-\tau)=m
$$

where $\tau$ is the corporate income tax rate (assumed to equal the capital income tax rate), $t^{s}$ is the shareholder income tax rate, and $m$ is the top marginal tax rate on labour income. The term $(1-\tau)\left(1-t^{s}\right)$ is the after-tax income left in the hand of the shareholder if he realizes a unit of labour income as a dividend or capital gain, while $1-m$ is the after-tax income earned when the income is paid out as a management wage or salary (which is deductible from the corporate tax base). The corporate tax rate would be chosen with a view to the international mobility of capital, while the choice of the top marginal labour income tax rate would involve considerations of equity, revenue and the potential international mobility of high-paid labour. The shareholder income tax rate $t^{s}$ would then have to be adjusted to roughly satisfy equation (10). Note that the value of $t^{s}$ implied by (10) would not necessarily correspond to the capital income tax rate, so in general

\footnotetext{
${ }^{13}$ Since non-listed shares are rarely traded, the problem would mainly relate to listed shares. Because trades in such shares are computerized, it should be possible to require financial intermediaries and professional traders to report investor holding periods to the tax authorities.
} 
shareholder income would be subject to a separate schedular tax rather than being included in the capital income tax base. ${ }^{14}$

It might be objected that choosing the shareholder income tax rate on the basis of the top marginal labour income tax rate could imply overtaxation of the labour income of active shareholders relative to the labour income of proprietors and wage earners, since the two latter groups will face a lower average tax rate on labour income under a progressive tax schedule. However, if controlling active shareholders wish to take advantage of the low marginal tax rates at the bottom of the labour income tax schedule, they can usually do so by paying themselves wages or salaries rather than dividends or capital gains, so the potential horizontal inequity mentioned is hardly a serious one.

In principle, the shareholder income tax utilizes the very same information on dividends, acquisition prices and realized sales prices which is needed to implement a conventional income tax on dividends and on realized capital gains on shares. However, under a conventional capital gains tax the tax authorities do not need to verify the basis value of the share until the time it is realized. Since many unquoted shares are never traded, this reduces the need for checking the basis value of shares. Under the shareholder income tax the basis value of the share must be determined already when it is acquired, and the basis must be stepped up every year in case of unutilized rate-of-return allowances. In practice tax administrators will therefore have to process more information under the shareholder income tax than under a conventional capital gains tax. On the other hand, it will often be easier to document and verify the acquisition price of a share at the time of purchase than when it is subsequently realized.

\subsubsection{Another alternative: a dual income tax with an Allowance for Corporate Equity}

The shareholder income tax described above is a residence-based personal tax on the worldwide income from shares. Through the rate-of-return allowance, the shareholder income tax offers relief for the double taxation of corporate income.

As an alternative to alleviating the double taxation of corporate income at the individual shareholder level, relief could be granted at the corporate level. For example, in line with the so-called ACE proposal by the Institute for Fiscal Studies (1991), companies could be allowed to deduct an imputed normal return on their equity (or on new equity formed after the reform), just

\footnotetext{
${ }^{14}$ In Norway shareholder income is treated as capital income and the capital income tax rate is set equal to the corporate tax rate. These choices have pedagogical advantages, but they also mean that equation (10) leaves less flexibility in the choice of the top marginal labour income tax rate.
} 
as they are currently allowed to deduct interest on debt. Under a DIT with an ACE system, a separate shareholder income tax would no longer be needed to prevent income shifting, provided the flat capital income tax rate $t$ applying to dividends and capital gains (as well as to other forms of capital income) were chosen such that

$$
(1-\tau)(1-t)=1-m
$$

since the total corporate and personal tax burden on labour income realized as dividends or capital gains would then equal the marginal tax burden on wage income. Further, the ACE allowance granted at the corporate level would ensure that dividends and capital gains would only be taxed at the shareholder level at the capital income tax rate $t$ as long as they do not exceed the imputed normal return to the company's equity. ${ }^{15}$

At least two arguments can be given in favour of double tax relief at the company level rather than at the shareholder level. First, for companies with access to the international equity market, tax relief at the level of domestic shareholders may not be very effective in reducing the cost of capital, since the cost of equity finance for these companies tends to be determined by the returns required by international investors who are not affected by domestic personal tax rules. By contrast, relief at the level of domestic (resident) companies would significantly strengthen the incentive for domestic investment, including inward direct investment by foreign multinational enterprises. Second, double tax relief at the corporate level would presumably be simpler to administer than a shareholder income tax with a rate-of-return-allowance, since the latter tax involves large numbers of taxpayers and transactions.

A further attraction of the ACE system is that it offsets the investment distortions caused by deviations between true economic depreciation and depreciation for tax purposes. If firms write down their assets at an accelerated pace, the current tax saving from accelerated depreciation will be offset by a fall in future rate-of-return allowances of equal present value, since accelerated depreciation reduces the book value of the assets (and hence the equity base) to which future rates of return are imputed. In fact, regardless of the rate at which firms write down their assets in the tax accounts, the present value of the sum of the capital allowance and the ACE allowance will always equal the initial investment outlay, so the ACE system is equivalent to the immediate expensing of

\footnotetext{
${ }^{15}$ Note that when tax rates are set in accordance with (11), the capital income tax rate will generally differ from the corporate tax rate.
} 
investment allowed under a neutral cash flow tax, as explained by Griffith, Hines and Sørensen (2008, sec. 6.3).

One potential drawback of combining a DIT with an ACE system is that the capital gains on shares generated by retained earnings benefit from the deferral of tax until the time of realization. Hence normal returns retained within companies might be undertaxed since they would not bear corporation tax, due to the ACE allowance. Corporate-source labour income and rents realized as capital gains on shares would also be undertaxed, for although these incomes would be subject to corporation tax as they accrued (since by assumption they would exceed the ACE allowance), they should ideally be taxed at the same total marginal rate as labour income at the time of accrual. Thus there would be a tax incentive to accumulate income within the corporate sector, generating an undesirable lock-in effect. However, to offset the compound interest gain interest gain from tax deferral in a rough manner, policy makers could decide to make a schematic upward adjustment of realized taxable gains that would increase systematically with the length of the holding period, in line with the proposal by Vickrey (1939). ${ }^{16}$ This would tend to eliminate the tax advantage to corporate-source income and rents which are realized in the form of capital gains (e.g. as stock compensation). Moreover, since holdings of listed shares are recorded in the computer registers of financial intermediaries and stock exchanges, it should be possible to tax the gains on listed shares already at the time of accrual, since this would not seem to involve any serious valuation and liquidity problems. In that case the adjustment for the length of the holding period would only have to be applied when taxing gains on non-listed shares which are rarely traded.

While an ACE system would generally provide a stronger stimulus to domestic investment than a shareholder income tax with a rate-of-return allowance, it would also cause a larger fall in tax revenues, since the RRAs under the shareholder income tax are only granted to domestic personal shareholders, whereas ACE relief at the corporate level benefits all holders of

\footnotetext{
${ }^{16}$ To eliminate the interest gain from tax deferral, one can show that a capital gain realized after a holding period of $n$ years should be adjusted upwards through multiplication by the factor

$$
\frac{g \cdot(1+r)^{n}}{(1+g)^{n}-1}\left[\frac{1-\left(\frac{1+g}{1+r}\right)^{n+1}}{1-\left(\frac{1+g}{1+r}\right)}\right]
$$

where $r$ is the after-tax interest rate and $g$ is the average annual percentage capital gain. If the asset was bought at the price $A_{b}$ and sold $n$ years later at the price $A_{s}$, the deemed annual capital gain would be calculated from the equation

$$
A_{s}=(1+g)^{n} A_{b} \text {. }
$$

Given knowledge of the buying and selling prices and the length of the holding period, tax administrators could thus use standard tables to calculate the adjustment factor needed to offset the deferral advantage. Note, though, that this method will only provide an imperfect offset to the benefit from tax deferral when capital gains accrue at an uneven pace over time.
} 
shares in domestic companies, including foreign investors and tax exempt institutional investors. Hence tax relief would be given even in cases where no domestic tax is paid on the imputed return. Moreover, in cases where the home countries of foreign investors would have granted a foreign tax credit for the corporation tax paid to the domestic source country, exempting the imputed normal return from domestic company tax is simply a give-away to the foreign fisc that does not improve the incentive to invest in the domestic economy.

The revenue loss from an ACE system could be limited by granting the allowance only for additions to the equity base undertaken after the time of reform. This would fully preserve the incentive to undertake new investment without bestowing a windfall gain on the owners of 'old' capital already installed. Presumably such a system would have to be supplemented by certain antiavoidance rules to prevent existing companies from liquidating and then starting up as new companies in order to qualify for an ACE allowance for all of their equity.

\subsection{The taxation of small companies in the Nordic countries}

The previous sections discussed alternative ways of taxing income from closely held corporations under a dual income tax, assuming that policy makers give high priority to the goal of tax neutrality. The present section briefly summarizes actual tax practices in the Nordic countries.

Finland and Sweden both have special tax rules for the owners of closely held companies. ${ }^{17}$ Until 2005, Finnish tax law required that the 'grossed-up' dividends from shares in non-listed companies exceeding an imputed return to the company's net assets be taxed as labour income, with a credit being granted for the underlying corporation tax. Dividends below the imputed return were effectively exempt from tax at the shareholder level, as a consequence of the Finnish imputation system and the correspondence between the tax rates on corporate and capital income. Realized capital gains on shares were fully taxed as capital income. To reduce the tax incentive for owners of small companies to transform labour income into capital gains, Finland has thus accepted double taxation of retained corporate earnings.

From 2005 Finland has abolished her imputation system. To maintain some alleviation of double taxation, only 70 percent of dividends from quoted companies are included in the

\footnotetext{
${ }^{17}$ Denmark does not have special tax rules for closely held companies. Instead, the country relies on a separate schedular progressive tax on dividends and capital gains on shares to ensure that the total corporate and personal tax burden on corporate equity income is roughly in line with the marginal tax rate on labour income.
} 
shareholder's capital income. For unquoted companies any dividend below the imputed return is tax exempt in so far as it does not exceed 90,000 euros for the individual shareholder. 70 percent of any dividend above this limit is included in taxable capital income, as long as the dividend remains below the imputed return, while 70 percent of any dividend above the imputed return is included in taxable labour income. Essentially Finnish tax law thus includes a schematic version of the shareholder income tax for unquoted companies, combined with partial double tax relief for quoted companies.

Until recently Sweden also allowed an imputed return to be deducted from the taxable income from shares in unquoted companies. However, from 2006 this rate-of-return allowance was replaced by a reduced tax rate on dividends and capital gains on unquoted shares (see notes 3 and 5 in Table 1). To address the income shifting problem, Swedish tax law imposes progressive labour income tax on dividends and realized capital gains above an imputed return to the basis value of shares in closely held companies. However, this is only done for shareholder income realized by 'active' shareholders carrying out a certain amount of work in their own companies. If the dividend or realized capital gain falls short of the imputed return in any year, the residual amount is carried forward with interest and added to the amount of shareholder income that may be taxed as capital income in the future.

From the introduction of the DIT in 1992 until the end of 2005, Norway treated 'active' shareholders in much the same manner as the self-employed, applying a (complex) version of the income-splitting scheme described in subsection 2.2.2. However, because of the difficulties of distinguishing between active and passive shareholders, Norway abolished the special tax rules for active shareholders from January 1, 2006, replacing them by a shareholder income tax which applies to all individual resident shareholders. Various aspects of this new Norwegian tax regime were analysed in subsection 2.2.3.

\section{PART 3. WOULD A DUAL INCOME TAX BE RELEVANT FOR NEW ZEALAND?}

New Zealand is currently considering the longer term needs for adjustment or reform of her personal and corporate income tax system. This final part of the paper therefore offers some brief observations on the possible relevance of the DIT as a blueprint for a future New Zealand tax reform. 
The DIT was developed in the Nordic countries which have large public sectors, relying on total tax revenues in the range from 45-50 percent of GDP, and which have historically had rather ambitious goals regarding the redistribution of income. As a consequence, the Nordic welfare states necessarily impose high tax burdens on labour income in the form of personal income taxes and social security contributions. ${ }^{18}$ Historically, the Nordic personal tax systems have been based on the philosophy of comprehensive income taxation, although in practice many forms of capital income have enjoyed favourable tax treatment. The DIT system emerged as the Nordic governments gradually came to acknowledge that taxing (some forms of) nominal capital income at the high marginal tax rates applied to (high levels of) labour income created intolerable distortions and horizontal inequities in an environment where capital was becoming increasingly mobile relative to labour and where some forms of capital income could not be subject to (full) tax, for practical or political reasons.

The current situation in New Zealand differs from that in the Nordic countries in some important respects. First, at around 38 percent of GDP, the total revenue collected by the New Zealand government is somewhat smaller. Second, the international mobility of labour in New Zealand is among the highest in the world, and much higher than in the Nordic countries. In particular, the labour markets of New Zealand and Australia are highly integrated. Both of these characteristics of the New Zealand economy suggest that the case for the DIT may be weaker in this country than in the Nordic countries.

In principle, the current personal tax system in New Zealand is based on the idea of comprehensive income taxation, although important items such as capital gains and imputed rents on owner-occupied housing are excluded from the tax base. Marginal personal tax rates are modest by Nordic standards, with a top rate of 39 percent. However, for families with children, the abatement of the Working for Families tax credit means that the effective marginal tax rate often increases by 20 percentage points, adding considerably to the progressivity of the tax-transfer system and raising the effective marginal tax rate to 59 percent for many taxpayers.

According to the New Zealand Treasury (2008), this effective top marginal tax rate applies to some, but far from all forms of capital income. Apart from the tax exemption for capital gains and imputed rents, the tax code also allows favourable tax treatment of investments channelled through a number of special vehicles.

\footnotetext{
${ }^{18}$ Denmark stands out from the other Nordic countries by having virtually no social security taxes, relying instead on the personal income tax, much like New Zealand.
} 
The corporate income tax rate in New Zealand currently stands at 30 percent. The double taxation of dividends is alleviated through an imputation system granting individual shareholders a full credit for the underlying corporation tax against the personal tax on dividends. Double taxation of retained earnings is avoided through the exemption of capital gains from personal income tax.

To reduce distortions to the pattern of saving and investment, it seems that New Zealand could benefit from moving towards a more uniform taxation of the various forms of capital income. At the same time the high mobility of the labour force and the competition for high-skilled labour across the Tasman Sea suggests the desirability of taking down the high effective marginal tax rates on labour in New Zealand.

Against this background, one option for personal tax reform might be to maintain and indeed strengthen the philosophy of comprehensive income taxation by broadening the capital income tax base (and perhaps the tax base more generally) while reducing marginal tax rates so as to align the top marginal personal tax rate with the current corporate tax rate of 30 percent. Assuming that the imputation system for dividend taxation is preserved, the corporation tax would continue to serve as a withholding tax. If capital gains on shares were included in the personal tax base, the double taxation of retained corporate profits could be alleviated by allowing shareholders to add (their proportionate share of) retained taxable profits to the basis of their shares when calculating the taxable capital gain on shares, in line with previous Norwegian practice (see section $1.1)$.

However, a reform along the lines suggested above would still leave several potential problems: First, if the abatement of tax credits and benefits like the Working for Families (WfF) credit were based on comprehensive income, the effective top marginal tax rate - including the top marginal rate on capital income - would still be quite high, at around 50 percent given current abatement rules. Levying such a high effective marginal tax rate on realized nominal capital gains would undoubtedly create serious and potentially unacceptable lock-in effects. On the other hand, if capital gains were left out of the base for calculating eligibility for the various tax credits, they would still benefit from favourable tax treatment relative to other forms of capital income, thus compromising the goal of tax neutrality underlying the reform. In response to this problem, policy makers might decide to grant tax credits like the WfF only on the basis of the taxpayer's labour income, but in that case they would face the same problems of separating capital income from labour income as those arising under a DIT. 
Second, even abstracting from the complications arising from the abatement of the $\mathrm{WfF}$ and other benefits, the so-called inflation argument in favour of the DIT would still apply: taxing returns to nominal assets at the same marginal rate as labour income implies that the real asset returns are overtaxed, due to the lack of inflation adjustment.

Third, the current corporate tax rate of 30 percent is relatively high compared to the corporate tax rates in other small OECD economies, so the forces of tax competition will most likely call for a lowering of the corporate tax rate in New Zealand in the medium and long term. This would open a gap between the personal capital income tax rate and the corporate rate if the principle of comprehensive personal income taxation were maintained. Given the benefits from tax deferral under a realizations-based capital gains tax, such a gap could generate an undesirable lockin of capital in existing corporations. To fix this problem, it would be necessary to adjust for the length of the holding period when levying capital gains tax, as discussed in subsection 2.2.4. In addition to this complication, the tax system would be complicated by the mechanisms needed to alleviate the double taxation of distributed as well as retained profits, as mentioned above. It is not obvious that such a tax system would be easier to administer than, say, a DIT with a shareholder income tax along the current Norwegian lines or a DIT with an ACE.

Against this background, despite the structural differences between the Nordic economies and the New Zealand economy, there may still be a case for considering the introduction of some version of the dual income tax in New Zealand.

\section{REFERENCES}

Auerbach, A.J. and D. Bradford (2004), Generalized cash flow taxation, Journal of Public Economics 88, 957-980.

Cnossen, S. (2000), Taxing capital income in the Nordic countries: a model for the European Union?, in S. Cnossen (ed.), Taxing Capital Income in the European Union - Issues and Options for Reform, Oxford University Press.

Eggert, W. and B. Genser (2005), Dual income taxation in EU member countries, CESifo DICE Report 3 (1), 41-47.

Fuest, C. and A. J. Weichenrieder (2002). Tax competition and profit shifting: On the relationship between personal and corporate tax rates. IFO-Studien 48, 611-632. 
Griffith, R., J. R. Hines and P.B. Sørensen (2008). International capital taxation. Forthcoming as Chapter 10 in The Mirrlees Review: Reforming the Tax System for the $21^{\text {st }}$ Century, to be published by the Institute for Fiscal Studies, London.

Hagen, K.P. and P.B. Sørensen (1998), Taxation of income from small businesses: Taxation principles and tax reforms in the Nordic countries, Ch. 2 in P.B. Sørensen (ed.), Tax Policy in the Nordic Countries, Macmillan Press.

Hall, R.E. and A. Rabushka (1995). The Flat Tax. Second Edition, Stanford: Hoover Institution Press.

Institute for Fiscal Studies (1991), Equity for Companies: A Corporation Tax for the 1990s. A Report of the IFS Capital Taxes Group. London: The Institute for Fiscal Studies, Commentary 26.

Jacobs, B. and A.L. Bovenberg (2008). Human capital and optimal positive taxation of capital income. Working Paper, Netspar, Tilburg University.

Keen, M., Y. Kim, and R. Varsano (2006). The 'Flat Tax(es): principles and evidence. IMF Working Paper, WP/06/218, International Monetary Fund.

Keuschnigg, C. and M. Dietz (2007). A growth-oriented dual income tax. International Tax and Public Finance 14, 191-221.

New Zealand Treasury Department (2008). Medium Term Tax Policy Challenges and Opportunities. Mimeo, Wellington.

Nielsen, S.B. and P.B. Sørensen (1997). On the optimality of the Nordic system of dual income taxation. Journal of Public Economics 63, 311-329.

Sinn, H.-W. (2007). Can Germany Still Be Saved? MIT Press, Cambridge, MA.

Spengel, C. and W. Wiegard (2004). Dual income tax: a pragmatic reform alternative for Germany. CESifo DICE Report 2 (3), 15-22.

Sørensen, P.B. (1994), From the global income tax to the dual income tax: Recent tax reforms in the Nordic countries, International Tax and Public Finance 1, 57-80.

Sørensen, P.B. (2005), Neutral taxation of shareholder income, International Tax and Public Finance 12, 777-801.

Sørensen, P.B. (2007a). The Nordic dual income tax: principles, practices, and relevance for Canada. Canadian Tax Journal 55, 557-602.

Sørensen, P.B. (2007b). Can capital income taxes survive? And should they? CESifo Economic Studies 53, $1-57$. 
U.S. Treasury Department (1992). Taxing Business Income Once - Integration of the Individual and Corporate Tax Systems. Washington, D.C. 